There remains the question of what the Minister of Technology should do about the Atomic Energy Authority. Simple men will hope that he will now be emboldened to do at least those simple things which stare him in the face. For one thing, he should relinquish responsibility for thermonuclear fusion, which should now be with the Science Research Council on an elastic budget and not short commons by ministerial decree. The weapons laboratory at Aldermaston should be transferred from the AEA to one of the ministries, possibly the Ministry of Defence. The problem of what to do with Harwell is daunting by comparison, but there is a case for considering novel solutions such as the creation of several autonomous laboratories, with separate sources of finance, in one physical environment. The trading functions of the AEA, including the sale of fuel elements and of isotopes for research, could be separated into one commercially conducted nationalized industry, but this is hardly an urgent matter. The central need is to decide just what part will be played in the future development of nuclear energy by the men now engaged on design and development for the AEA. The solution which the select committee has proposed is only one of many. Another, for example, is that the AEA might be divided between the electricity boards and the industrial companies. For even though the select committee is probably right in saying that there is no prospect of anything approaching competition in the present circumstances in which three commercial enterprises compete for what little business there is to be had, and although everybody will agree that the companies should be more closely concerned with design and development, it is by no means obvious how this should best be done. Plainly the Minister of Technology will have to start where the select committee left off. He had better make haste.

\section{Japanese Science Policy}

SCIENCE in Japan comes under scrutiny in a recent study by the Organization for Economic Cooperation and Development (OECD, $£ 1$ 10s.). This is the seventh review of national science policy which the OECD has published; the others cover Sweden, Greece, Belgium, France, Germany and the United Kingdom. The review concludes that Japan suffers from an unwieldy advisory structure and a multiplication of laboratories too small to justify themselves. Advice is supplied by two principal organizations-the Council for Science and Technology, and the Science Council of Japan. The first of these, the report says, is too concerned with government affairs, while the second, whose relations with the government have for several years been in a permanent state of crisis, is too involved with academics. There are in addition four specialist advisory agencies, covering atomic energy, radiation, marine science and space.

Much of the direct administration of science in Japan is carried out by the Science and Technology Agency. The position of the agency is complicated, the report says, because it also acts as secretariat for the Council for Science and Technology and the four specialist agencies. Sometimes it is in the position of being both judge and advocate. Researoh conducted by other government ministries "presents a picture of extraordinary dispersal of effort". Often the effort is too small to meet the threshold requirements for concerted programmes of research. There is further danger, the report suggests, in the sharp division between funds for university research and for other research. This division represents a major obstacle in the development of coherent science policy.

Despite the success of Japanese industry since the War, the report suggests that there is still an overheavy reliance on imported technology. "There is still some way to go before Japanese technological innovation commands respect from those nations whose technology has been the basis for Japanese development." If Japan really does want more technological independence, it will have to pay more for it, by stimulating domestic innovation. The recent establishment of a Research Development Corporation to underwrite high-risk and development projects could help, the report concludes.

Japanese witnesses to the review body gave interesting details of a project intended to collect together a large number of the government's research institutes in a research park at. Mount Tsukuba. The plan sounds ambitious: the park will have several universities and some forty government institutions, as well as some private ones. The park will be some 50 kilometres from Tokyo, and an express highway will be built between the two. At the moment land is being obtained, and construction will begin next yearwithin ten years the park should be complete. The park will include a great variety of institutions, including pure science, architecture, mechanical engineering, disaster prevention, medicine and agriculture.

\section{Fewer Claims on Oxford}

\section{by our Oxford Correspondent}

Applications for admission to Oxford University fell by 8.5 per cent this year. It is, of course, too early to say whether this was caused by a loss of interest in the older universities among sixth formers, or indeed whether the decrease is significant at all. There may not have been any change in the quality of candidates-examination scripts are only being marked now-so that the fall in numbers may merely result from stiffer pre-selection of candidates by the schools.

But, in any case, long before the fall in the number of applicants became known, the university decided to increase its contacts with the schools so as to encourage sixth formers to apply to Oxford. At large and well equipped schools, such as Manchester Grammar School, which sends 70 to 80 boys on to university each year, Oxford, with its college system and academic and administrative idiosyncrasies, is very much a known quantity. Such schools need no proselytes; candidates from them are many and well informed. But at smaller schools, where a tradition of entrance to universities has not been established, Oxford may be regarded with a certain amount of awe, a distant and perhaps unsympathetic institution, little interested in applicants from unknown schools. One head master, for example. has commented on the fact that some Oxford women's colleges used not to make past examination papers 


\section{All Change on Aldabra}

The Under-Secretary of State for Defence for the Royal Air Force (Mr Merlyn Rees): “. . . I want to make it abundantly clear at the outset-and this to a very large degree limits my remarks this evening-that no decision has yet been made whether or not to use the island of Aldabra for defence purposes. As my right hon. friend the Secretary of State for Defence assured the House on 5th July, the scientific issues at stake will be taken carefully into account in reaching any decision." Hansard, Col 1845, October 25, 1967.

The Prime Minister (Mr Harold Wilson): “. . In overseas terms, we have decided not to proceed with the Aldabra project-(Interruption) - the establishment of a staging post in the British Indian Ocean territory. As far as we can at present estimate, it should mean that expenditure next year will cut defence spending to the level which last July, with great difficulty, we had scheduled for 1970-71. It is an advance from 1970-71 to 1968-69-I think a remarkable achievement." Hansard, Col 1341, November 22, 1967.

available to applicants, so that only schools which regularly sent in entrants could collect papers for the aid of future candidates. (This anomaly has now been cleared away. From this year onwards the Colleges Admissions Office will deal with women's applications as well as men's.) Relations between schools such as these and the newer universities have been much stronger: Leeds University has been particularly active in sending members of its staff to talk to sixth formers. At the University of East Anglia, a report on a student's work in his first year is sent back to his school, and Sussex University gives an account to the school of how its candidates fare at the entrance interview.

This is not to say that Oxford has been entirely idle, for more and more candidates have been coming from state schools in recent years. But recruitment has largely been left to individual colleges. Last summer, the Colleges Admissions Office began arranging with a number of schools that Oxford dons should come and talk to sixth formers or staff about any problems there might be in applying to Oxford. It is hoped that the first visits may be made next term so that it might be possible to gauge the success of the scheme by the entrance figures for next year.

\section{More Big Spending}

BRITAIN should go ahead and support the plan to build the CERN $300 \mathrm{GeV}$ machine, according to Professor P. M. S. Blackett, President of the Royal Society. In his presidential address at the anniversary meeting of the society on November 30, Professor Blackett said that the big machine would provide a natural follow-up to the "brilliantly successful" $28 \mathrm{GeV}$ machine at Geneva. There was wide agreement on scientific grounds that the machine should be built, he said, but doubt had arisen because of its great cost. "Some scientists fear that the fifteen years or so forward commitment which such a big project requires could put at risk the provision of adequate finance for the great bulk of little science, which cannot be planned far ahead. After careful thought on all these matters, I am convinced that Britain should decide to join in this great and exciting European venture-and the sooner the better."

Professor Blackett went on to suggest that in reality there was no real conflict between big and little science. of course, it was possible that the demands of big science would starve little science of funds, but in
Britain this had not happened. The big spenders-nuclear physicists, high energy physicists, space scientists and radio astronomers-had beaten a path to the Treasury door and made it easy for little science to follow. "In short, the big sciences have raised the scale of expenditure on research to a new level, and this has carried little science in its wake."

Professor Blackett spoke with great enthusiasm about the increased level of exchanges within Europe, and the new arrangements for which the Royal Society is acting as a clearing house. And, in spite of the other demands on national resources, Professor Blackett said he was convinced that the rate of growth of the science budget should remain high for a long time yet. This called for very careful selection of projects for support, and some scientists were bound to feel frustrated-the biggest protests, he said, were likely to come from those who had been best fed in the past. A close comparison with manufacturing industry could be made-many firms work very hard to make their tenders for a given contract. But only one firm wins it. So it must be with British scientists, Professor Blackett concluded.

\section{Royal Society Blooming}

THE move to new premises seems to have left the Royal Society in a cheerful frame of mind even if the appeal for funds to pay for the capital cost of conversion is still some $£ 200,000$ short of the target of $£ 850,000$. In practice the programme of exchanges with European countries seems to have captured a good deal of the society's enthusiasm. The society describes its operations in the year past as "a very successful start to a new programme". There seems every prospect that the work of the past year will be increased in the months ahead and that European countries will come forward with proposals for spending money which will allow the Royal Society to draw more heavily on the British Government in support of the programme of exchanges. In the year ahead, $£ 50,000$ has been made available by the Government for this work.

Government spending through the society is increasing steadily. In the year to last April, a total of $£ 564,000$ was spent in this way, roughly a quarter of it on the support of scientific research. The society spends roughly the same amount of government money — 146,300 - on participation in international ventures, mostly through the International Council of Scientific Unions. 